\title{
THE CHARACTERISTICS OF BEHAVIOR OF DEAF AND HARD-OF-HEARING LEARNERS IN DIFFERENT TYPES OF SCHOOL ENVIRONMENT
}

\section{Ivana Roksandić ${ }^{1}$ \\ Ivana Pavković \\ Jasmina Kovačević}

Elementary school "Radivoj Popović", Zemun

Life Skills Improvement Center-Belgrade

Faculty for special education and rehabilitation - University of Belgrade

\author{
Original scientific paper
}

Received: 18.12.2017

Accepted: 15.1.2018

\begin{abstract}
The school environment is a context that provides students with the opportunity to acquire certain skills during regular teaching, extracurricular and other activities, as well as to manage social relationships, adapting their behavior to specific social demands and interactions. The results of a large number of surveys indicate the specificities and shortcomings in social adaptation, communication, education, problems in the behavior of deaf and hard-of-hearing learners that result from primary damage. This paper analyzes the behavior of deaf and hard-of-hearing students who are educated in regular schools and schools for deaf and hard-of-hearing students, especially aspects of behavior during the class, at the break time, towards friends as well as their emotional attitude. The similarities and the differences in the behavior of deaf and hard-of-hearing learners in different types of school environment are highlighted. Finally, some general guidelines for the approaches to the development of individual educational models of support for deaf and hard-of-hearing students are given. The pointed out fact is the importance of the participation of defectologists in the inclusive school environments in order to provide the expert guidance to the teachers, the teaching staff and theparents in order to create an incentive environment for the development of positive interactions and forms of behavior for deaf and hard-of-hearing students.
\end{abstract}

Keywords: behavior, deaf and hard-of-hearing students, school environment

\section{INTRODUCTION}

The school environment is a context that provides students with the opportunity to form positive behaviors during regular teaching, extracurricular and other activities, and develop and build the so- cial relationships (Roksandić \& Kovačević, 2016). The research shows that students who have positive interactions with peers also have better school achievements, positive attitudes towards school and learning and manifest the prosocial behavior (Berndt, 1996).

\footnotetext{
${ }^{1}$ Correspondence to:

Jasmina Kovačević, University of Belgrade, Faculty of Special Education and Rehabilitation

Visokog Stevana 2, 11000 Belgrade, Serbia

Phone: +38765 2052771

E-mail: kovacjasmina@gmail.com
} 
Also, students who exhibit responsible behavior and who are accepted by peers achieve better school results than peers who are socially rejected and unadjusted (Chen et al., 1997; Green et al., 1980; Hatzichristou \& Hopf, 1996; Welsh et al., 2001; Wentzel, 1991a; Wentzel \& Asher, 1995). Similar studies have shown that the positive interaction among students contributes to the motivation for work and learning (Hartup, 1985). Namely, the positive interaction, in addition to facilitating the adoption and understanding of content, improves self-esteem and increases emotional support and thus directly contributes to the overall intellectual development of the students (Wentzel, 1991a).

In deaf and hard-of-hearing students, the consequences of the primary damage are complex and significantly reflect on a number of the developmental aspects. Differences occur often in social adaptation, communication, education, behavioral problems (Hauser, 2006; Wool, 2008).

Whitaker and associates emphasize behavior as one of the leading factors in building an effective school and achieving positive educational and social outcomes (Whitaker et al, 2008). The authors emphasize the aspect of communication that applies to all participants in the teaching process from the students and the teachers to the technical staff and the school management. The two-way communication, transparency of communication and timely information are key to achieving the success. This creates an incentive teaching and working environment, raises motivation and creates a positive atmosphere. They further emphasize observation as a systematic monitoring of the work of all employees, mutual cooperation, and professional development. In addition to the communication and observation, they put special emphasis on relationships, for which the work is needed to create an incentive climate and develop a cooperative approach among all participants in the teaching process, including parents and the local community. Also, the expectations related to setting standards in relation to the behavior of students and teachers are highlighted. The research shows that the condition of the auditory dysfunction determines the specificity of social development and social communication of deaf and hardof-hearing children, and there are often present manifestations in the form of unadjusted behavior, reduced communication with the environment, frequent withdrawals and social isolation. In addition, there is also the inability to control their own behavior and accept responsibility for their actions, disregard for social norms and specific deviations in moral development and moral reasoning (Brajović et al., 1997). The inad- equate communication among deaf and hard-of-hearing learners due to limited language development is the cause of frequent behavioral rigidity (Kovačević, 2016).

Most deaf and hard-of-hearing students finish a school with poor linguistic abilities and speech-reading skills, not higher than the normally-hearing population (Conrad, 1979). The very low level of school achievement of deaf children is associated with the inadequate speech-language development, a poor vocabulary, and therefore insufficient understanding of instruction during the class, as well as a lower degree of motivation for achieving better school success (Brasel \& Quigley, 1977; Lewis, 1996). In addition, there is a characteristical existence of limited interests, a feeling of less value, dissatisfaction with oneself, identification problems, and there are often symptoms of depression and anxiety (Tambs et al., 2007).

The examination of the sense of loneliness and coherence in deaf and hard of hearing children in special classes at regular schools as well as in inclusive classes shows that there are no significant differences between these two groups of students. However, students attending special classes in regular schools have a significantly lower average grade of comprehensibility of speech than students in inclusive classes. The author emphasizes the importance of good comprehension of the speech, not only for the successful communication but also for the unhindered social and emotional development of the child and successful social integration (Most, 2007).

As a result of the inadequate communication with the environment, there is often a manifestation of distrust towards the environment and a feeling of insecurity, affective reaction and a changeable mood (Pavković, 2016).A study of the frequency of problems in the behavior of deaf children and children with cochlear implants compared to children who regularly hear has shown the existence of a relationship between behavioral problems and the level of speech-language development. The frequency of psychosocial difficulties is reduced with a greater degree of language development, either oral or sign language, which affects the successful social integration of deaf children (Kovačević, 2016; Dammeyer, 2010; Jiménez-Romero, 2015).

The results of the study on the influence of family and peers on the pupil behavior show that the peers in the adolescent period increase their interaction with each other, while the influence of the family does not decrease. 
Specifically, strong relationship with parents do not necessarily imply a weak relationship with their peers, and vice versa (Krnjajić). The results of the study of the relation between the environment in which the deaf and hard-of-hearing children live and the expression of behavioral problems and emotional problems show that students living in the families find it more difficult to establish communication with people whom they do not know well, they are nervous and often worried, while differences in the behavior have not been determined (Kovačević , 2016). In the period when children start to establish more intense social contacts outside the family, a more intense peer influence begins not only on the behavior level but on the overall functioning of the child. In this way, families and schools are the most responsible for providing the curriculum, models of individual support and educational models that enable optimal intellectual, social, moral and emotional development of pupils.

At school, a systematic planned and organized learning process is realized, which enables students to acquire certain knowledge as well as to manage social relations, adapting their behaviour to specific social demands and interactions. The success of the deaf and hard-of-hearing learners regardless of the environment, regular and "special school" depends on many factors, but a significant influence in addition to their work habits and attitudes toward learning and school obligations is their behavior during the class and during extracurricular activities as well as their emotional attitude.

In order to take into account the characteristics of the behavior of deaf and hard-of-hearing students in different types of school environment, regular and "special" schools, and to highlight similarities and differences, a comparative analysis of two surveys that addressed this problem was done.

Pavković's research (2016) was conducted in regular schools on a sample of 30 deaf students on the territory of the Republic of Serbia. In order to analyze the assessment of the behavior of deaf students in a regular school, a questionnaire was constructed, modeled on the Savanović-Bojanin test (1976/90). Roksandić's research (2016) on the behavior of deaf and hardof-hearing students in schools for impaired pupils was carried out on a sample of 59 deaf and hard-ofcharge students attending schools for deaf and hardof-charge students on the territory of the Republic of Serbia. A questionnaire for teachers was used to analyze the assessment of the behavior of deaf and hard- of-hearing students in the school (Stanojlović, 2012). The questions presented in both tests dealt with behavior at school - addressing the teacher, mood at the break time, behavior at break time towards the other children, behavior at break time while playing, behavior at the break time in the yard, mood during the class, attention of students during the class, behavior during the class towards the other students.

\section{Behavior of deaf and hard-of-hearing learners in different types of school environment}

In order to achieve positive educational outcomes at school, the norms which govern social interaction in the classroom are the most important - first of all rules relating to mutual respect and cooperation, respect for the other, co-operation and readiness for mutual and group work (Sheridan, 1995). Respecting and internalizing these rules is a precondition to creating a rewarding learning environment for an effective teaching process (DeVries \& Zan, 1994). Socially responsible behaviour involves acceptance of the expected roles, social rules and moral values (Gresham, 1986). Consequently, socially responsible behavior, i.e. instilling values such as accuracy, diligence, reliability, responsibility for learning and school obligations in children, is an important educational goal.

The social participation of students with disabilities in a regular school involves the presence of positive interactions among peers, their acceptance by peers, friendship with peers, and the experience of acceptance in the class. Social participation of children with disabilities is one of the main motives of parents when enrolling a child in a regular school. The results of the survey show that attending regular school does not necessarily mean an increase in the number of contacts and friendships with peers (Pijl, 2005). Namely, the creation of close relationships is connected with the children's ability to communicate with other people. The results of the studies point to the existence of deviations in the social and emotional development of deaf and hard-of-hearing children in the field of communication, moral development, solving social problems, areas of empathy and social perception (Suarez, 2000).

An analysis of the research results of Roksandic (2016) on student behavior in the school environment, "special" school indicates that when it comes to behavior in the class, pupils exhibit coherent behavior in the largest percentage. 
Addressing the other students is consistent and, if necessary, careful attention is being paid to the mood (Table 1). The results of the Pavković's research (2016) on behavior in the school environment, regular school, show that when it comes to behavior of pupils in class, the largest percentage also shows coherent behavior, they carefully monitor and they reduce their negative mood. On the one hand, the similarity in the behavior of deaf and hard-of-hearing students in a completely different school environment stems from the realization of a set of traditional and respected educational goals, which is the development of social skills, positive social interaction, adapting to social rules and adopting moral values. These outcomes are defined by school rules that at the same time send pupils to a cooperative relationship, respect and constructively solve problems, but also discourage students from displaying negative behaviors.

On the other hand, behavioral differences were observed in addressing other students and the emotional attitude of students. In the regular school, deaf and hard-of-hearing pupils do not turn to anyone and have lowered moods, while in the school for deaf and hard-of-hearing students, peers often turn to the others because of the need and have a balanced mood with a situation in class (Table 1). The first obstacle in contact and building friendship among deaf and hard-of-hearing students with peers of typical development is difficulty in communication. In addition, research suggests that deaf and hard-of-heart children have under-developed social skills appropriate to peer interaction, which is in accordance with the results of these two studies. Often the social interaction in a regular school is affected by misinterpretation of the communication needs of deaf and hard-ofhearing students, and the child's request for repetition of spoken language is often interpreted as a lack of consideration or a lack of ability to understand the content. Foreign researches indicate a uniform pattern of behavior in the interaction between deaf and hard-of-hearing peers and peers in a regular school which is characterized by more frequent interactions with the deaf children than with peers in the class who hear, but that mutual exposure can lead to an increase in interaction (Weisel et al, 2005; Kluwin et.al 2002).

Table 1 Behaviour of deaf and hard-of-hearing students in the class in a diverse school environment

\begin{tabular}{|c|c|c|c|}
\hline \multicolumn{2}{|l|}{ Type of school environment } & \multirow{2}{*}{$\begin{array}{l}\text { Regular } \\
\text { school } \\
\%\end{array}$} & \multirow[t]{2}{*}{$\begin{array}{l}\text { School for deaf } \\
\text { and hard -of - } \\
\text { hearing students }\end{array}$} \\
\hline & & & \\
\hline \multirow[t]{3}{*}{ Behaviour in the class, sitting place } & Noticeably calm & 40.0 & 16.7 \\
\hline & In accirdance & 43.3 & 43.1 \\
\hline & Not patient & 16.7 & 40.3 \\
\hline \multirow{3}{*}{$\begin{array}{l}\text { Behaviour in the class towards } \\
\text { friends }\end{array}$} & Does not address anyone & 40.0 & 13.9 \\
\hline & Addresses if needed & 36.6 & 66.7 \\
\hline & Teasing & 0.0 & 19.4 \\
\hline \multirow[t]{3}{*}{ Behaviour in the class / patience } & Lack of patience & 20.0 & 16.7 \\
\hline & Follows carefully & 43.3 & 44.4 \\
\hline & Scatered attention & 3.3 & 38.9 \\
\hline \multirow[t]{3}{*}{ Behaviour in the class / mood } & Lowered & 54.0 & 23.6 \\
\hline & In accordance & 17.0 & 56.9 \\
\hline & Increased & 23.3 & 19.4 \\
\hline
\end{tabular}

Numerous studies deal with the question of the quality and quantity of social interactions among the deaf and hard-hearing learners and their peers of typical development in the regular education system and point to a series of adaptation factors for deaf and hard-of-hearing children (Martin \& Bat-Chava,
2003; Kersting, 1997). The research on the social functioning of the deaf and the hard-of-hearing child is directed at various aspects in the context of a "special", partially or completely inclusive class, as well as in interaction with peers with and without hearing impairment. 
General social maturity, relationship with parents and peers, social interaction and the importance of language for social development of the child are the most commonly used variables in the social development of deaf and hard- of- hearing children. Apart from the above-mentioned variables for a complete view of social interactions in a different school environment, students' behavior at break time, organized play, and interaction with other students are also significant.

The results of the research Pavković (2016) and Roksandić (2016) related to the behavior of deaf and hard-of-hearing students at the break time show that deaf and hard-of-heart pupils show coherent behavior, engage in peer-to-peer play and have organized activities. Furthermore, the results show that there is a positive interaction in the group, since most respondents accept other children, while in terms of feelings they display coherent moods (Table 2). The results of similar foreign studies show that students of typical development in regular schools are ready to accept their deaf peers (Kluwin et.al, 2002). However, although they were accepted by their peers of typical development, deaf and hard-of-hearing students perceived that relationship as less satisfactory. Namely, the results of the research using self-assessment of deaf and hard-of-hearing students show that their sense of connection with peers of typical development is considerably weaker than with deaf and hard of hearing students (Jolić \& Isaković, 2008).

Table 2 The behavior of deaf and hard-of-hearing students at the breaktime in a different school

\section{Type of school environment}

\begin{tabular}{ll} 
Regular & School for \\
school & deaf and \\
& hard -of - \\
& hearing \\
& students \\
\hline
\end{tabular}

Behaviour at the breaktime in the yard

Behaviour at the breaktime in the relation to the game

Behaviour at the breaktime in the relation to the group of children

Behaviour at the breaktime /mood

\section{Clumsy behaviour}

In accordance

Noticeably mobile

Does not participate in the game

Plays organised

Disturbs organised game

Does not notice

Accepts

Does not accept

Lowered

In accordance

Increased
16.7

30.0

10.0

0.0

30.0

26,6

0.0

80.0

20.0

10.0

20.0

23.3
9.7

66.7

23.6

29.2

62.5

8.3

22.2

69.4

8.3

22.2

18.1
In the school environment, students learn not only knowledge but also learn how to manage social relationships. Moreover, positive peer relationships contribute to the development of empathy and building a cooperative relationship with the others (Roksandic \& Kovačević, 2016). In addition, pupils' behavior and their proper emotional and mental development are significantly influenced by the interaction among teachers learners (Murray \& Pianta, 2007; Natvig et.al, 2003; Roeser, Eccles \& Sameroff, 2000). Whether the interaction among teachers and students will be open and motivating depends on the one hand on the style of teacher behavior, while on the other hand, it depends the personal characteristics of students. The positive emotional dimension of the teacher-student relationship creates conditions for the development of positive behaviors.

A comparison of the research results of Roksandic (2016) and Pavković (2016) points to the existence of differences in the attitude of the deaf pupils towards the teacher, the assignments, praises, and remarks (Table 3). 
The explanation of the obtained results can be found in the nature of hearing impairment that limits the communication skills and the lack of experience that deaf and hard-of-hearing learners obtain through interaction with other people resulting in difficulties in the social and emotional functioning of children (Edwards \& Crocker, 2008). For this reason, the achievement of positive educational outcomes, while respecting the individual potentials of deaf and hardof-hearing students in inclusive schools, requires well-planned and programmed content and activities, as well as competent teaching staff with positive pedagogical skills. It is necessary for the teacher to see and understand the needs, interests, and capabili- ties of each deaf and hard-of-hearing learner individually, and adapt the teaching style to their learning styles and abilities, or choose the level and form of help in relation to the specific needs of the individual. Accordingly, the involvement of defectologists is required to provide expert guidance to teachers in the planning and realization of teaching work and achieving a positive interaction with deaf and hardof-hearing students (Pavković, 2016). In addition, parents' participation in child's school activities can significantly contribute to academic success, and the level of communication skills of parents is a more important predictor of the overall socio-emotional and intellectual development of a child (Calderon, 2000).

Table 3 - The attitude of deaf and hard-of-hearing learners towards teachers in different school environments

\section{Type of school environment}

\begin{tabular}{llcc} 
& & $\%$ & $\%$ \\
\hline Addresses the teacher & Never & 10.0 & 16.7 \\
& As needed & 40.0 & 61.1 \\
\multirow{3}{*}{ Attitude towards tasks } & Asking questions & 50.0 & 22.2 \\
& Accepts confusingly & 57.0 & 15.3 \\
& Accepts normally & 20.0 & 58.3 \\
Praise & Stands up, walks & 0.0 & 26.4 \\
& Being ashamed & 0.0 & 14.1 \\
& Accepts normally & 23.3 & 53.5 \\
Remarks & Does not affect the behaviour & 16.7 & 32.4 \\
& & & \\
& Being ashamed & 57.0 & 26.4 \\
& Accepts normally & 26.7 & 47.2 \\
& Does not affect the behaviour & 16.7 & 26.4 \\
\hline
\end{tabular}

$\begin{array}{ll}\text { Regular } & \text { School for deaf } \\ \text { school } & \text { and hard -of - } \\ & \text { hearing students }\end{array}$

\section{CONCLUSION}

The school environment, regularly or "especially" strongly influences young people, especially the environment in which the individual characteristics of each student are respected. Inadequate auditive perception determines the specificity of social development and social communication of deaf and hard of hearing children, and there are often manifestations in the form of unadjusted behavior, reduced communication with the environment, frequent withdrawal and social isolation (Kovačević, 2016). Most of the previous research on the social development of deaf and hard-of-hearing students focused on the inclusive environment and examined the quality of their inter- action with peers of typical development, while fewer data on behavior and social adaptation of deaf and hard-of-hearing students in a "special" school environment. The purpose of this paper was to look at the characteristics of the behavior of deaf and hard learners studying in an inclusive education system and those in special schools. The synthesis of the results of the presented analyzes points to certain similarities in the behavior of deaf and hard-of-charge students in different types of school environment, but also to significant differences. Deaf and hard-of-hearing pupils, regardless of the type of school environment, show coherent behavior in the class and at the break time, they are attentive, involved in the game with peers in the organized game. 
Differences in behavior are observed in addressing other students, while in the regular school of deaf and hard-of-hearing students mostly do not address anyone, while at the school for deaf and hard-of-hearing pupils they most often address peers as needed. Also, there are significant differences in the attitude of the deaf students to the teacher, the assignments, praises, and remarks. Namely, in schools for deaf and hard of hearing pupils, the highest percentage of students addresses the teacher as needed and agrees to accept orders, compliments and teacher's remarks. In a regular school environment, the highest percentage of students are with lowered moods, asking teachers without any need, confusingly accepting the orders, praises accept normally but they are ashamed by the remarks.

The obtained research results point to possible ways to improve everyday pedagogical practice in the schools where the deaf and hard-of-hearing students are educated and create conditions for achieving positive teacher-student and student-student relationship, by upgrading the existing educational process.

The development of social skills and positive behaviors is an important and sufficient reason for changes in pedagogical work by improving the cooperation of defectologists, teachers, professional associates and the family. The planning of quality individual support in an incentive and supportive school environment creates the conditions for the overall development of deaf and hard-of-hearing students and their successful social integration.

\section{REFERENCES}

Berndt, T. J. (1996). Exploring the effects of friendship quality on social development. In W.M.Bukowski, A.F. Newcomb, \&W.W. Hartup (Eds.) The companythey keep: Friendship in childhoodand adolescence (pp.346-365). New York, NY: Cambrige University Pres.

Brajović, LJ., Matejic-Djuricic, Z., Radoman, V. \& Brajovic, A. (1997). Hearing and hearing impairments. Belgrade: Institute for Textbooks and Teaching Resources.

Brasel, K., \& Quigley, S. (1977). The influence of certain languageand communication environments in early childhood on thedevelopment of language in deaf individuals. Journal of Speech and Hearing Research, 20, 95-107

Bat-Chava, Y., Martin, D., \& Kosciw, J. G. (2005): Longitudinal improvements in communicational socialization of deaf children with cochlear implants and hearing aids: evidence from parental reports. Journal of Child Psychology and Psychiatry, 46:12, 1287-1296.

Calderon, R. (2000). Parental Involvement in Deaf Children's Education Programs as a Predictor of Child's Language, Early Reading, and Social-Emotional Development. Oxford Journals. Medicine \& Health \&Social Sciences. Jnl of Deaf Studies and Deaf Education, 5 (2), 140-155.

Chen, X. et al. (1997): Relations between academic achievement and social adjustment: evi-dence from chinese children, Developmental Psychology, 33(3), 518-525.

Conrad, R. (1979). The deaf school child.London: Harper and Row

Gresham, F.M. (1986): »Conceptual issues in the assessment of social competence in children«; in P.S. Strain, M.J. Guralnick \& H.M. Walker (eds.): Children's social behavior (143-179). Orlando: Academic Press

Dammeyer, J. (2010). Psychosocial development in a Danish population of children with cochlear implants and deaf and hard-of-hearing children. Journal of Deaf Studies and Deaf Education, 15(1), 50-58.

DeVries, R. \& Zan, B. (1994): Moral classroom, moral children. New York: Teachers College Press.

Edwards,L., \& Crocker, S.(2008). Psychological processes in desf children with complex needs: An evidence-based practical guide. London: Jessica Kingsley.

Green, K. D. et al. (1980). An assessment of the relationship among measures of children's social competence and children's academic achievement, Child Development, 51(4), $1149-1156$

Hartup, W. W. (1985). Relationships and their significance in cognitive development, in R.A.Hinde, A. Perret-Clermont \& J. Stevenson-Hinde (eds.). Social relationships and cognitive development. Oxford. Oxford University Press, 66-82.

Hatzichristou, C. \& D. Hopf (1996). A multiperspective comparison of peer sociometric s tatus groups in childhood and adolescence, Child Development, 67, 1085-1102.

Hauser, P. C., Wills, K. E. \& Isquith, P. K. (2006). Hard-of-hearing, deafness and being deaf. In J. E. Farmer, J. Donders \& S. Warschausky (Eds.), Treating neurodevelopmental disabilities:clinical research and practice (pp. 119-131) New York: Guilford Press.

Kersting, S. (1997): Balancing between deaf and hearing worlds: Reflections of mainstreamed colledge students on relationships and social interaction. Journal of Deaf Studies and Deaf Education 2:4, 252-263.

Kovačević, J. (2016). Problemi u ponašanju učenika sa oštećennjem sluha. Osnove problema u ponašanju kod studenata sa invaliditetom. Univerzitet u Beogradu. Fakultet za specijalnu edukaciju i rehabilitaciju.

Kluwin, T. N., Stinson, M. S., \& Mason Colarossi, G. (2002): Social processes and outcomes of in-school contact between deaf and hearing peers. Journal of Deaf Studies and Deaf Education 7:3, 200-213.

Krnjajić, S. (2002). Vršnjački odnosi i školsko postignuće. Zbornik Instituta za pedagoška istraživanja. Institut za pedagoška istraživanja. Beograd. 213-236.

Lewis, S. (1996). The reading achievement of a group of severelyand profoundly hearing-impaired school leavers educatedwithin an natural aural approach. Journal of the British Associationof Teachers of the Deaf, 20, 1-7.

Jiménez-Romero, M. S. (2015). The influence of cochlear implants on behaviour problems in deaf children. Psicothe$m a, 27(3), 229-234$.

Jolić, Z., \& Isaković, LJ. (2008). Socijalna kompetentnost gluvih I nagluvih učenika - poređenjesa vršnjacima koji čuju. Zbornik radova: U susret inkluziji - dileme $u$ teoriji $i$ praksi, Defektološki fakultet, Fakultet za specijalnu edukaciju i rehabilitaciju, ISBN 987-86-80113-71-5,Beograd. 
Martin, D., \& Bat-Chava, Y. (2003): Negotiating deaf-hearing friendships: coping strategies of deaf boys and girls in mainstream schools. Child:Care, Health \& Development, 29, 6, 511-521.

Most, T. (2007). Speech Intelligibility, Loneliness and Sense of Coherence Among Deaf and Hard/of/Hearing Children in Individual Inclusion and Group Inclusion J. Deaf Stud. Deaf Educ. 12 (4) 495-503. doi 10.1093/deafed/ enm015.

Murray C., \& Pianta R. C.(2007). The importance of teacherstudent relationships for adolescents with high incidence disabilities Theory Into Practice 46 105-112. doi:110.1080/00405840701232943

Natvig G. K., Albrektsen G., \& Qvarnstrøm U.(2003).Associations between psychosocial factors and happiness among school adolescents International Journal of Nursing Practice 9 166-175. doi:110.1046/j.14401172X.2003.00419.x

Pavković, I. (2016). Evaluacija uspeha učenika oštećenog sluha u redovnoj školi (doktorska disertacija). Beograd: Univerzitet u Beogradu -Fakultet za specijalnu edukaciju i rehabilitaciju.

Pijl, S. J. (2005). Interventies gericht op sociale integratie: Training van sociale vaardgheden voor leerlingen met beperkingen in het reguliere onderwijs (Interventions which aim at social intergration: Social skills for pupils with disabilities in mainstream education). In: Interventies in de orthopedagogiek, Edited by: van der Meulen, B.F., Vlaskamp, C. and van den Bos, K.C. 122-35,Rotterdam:Lemniscaat b.v.

Roeser R. W., Eccles J. S., \& Sameroff A. J.(2000). School as a context of early adolescents' academic and social-emotional development: A summary of research findings. The Elementary School Journal 100 443-471
Roksandić, I., \& Kovačević, J. (2016). Saradnja porodice i škole u prevenciji školskog neuspeha gluvih i nagluvih učenika. Specifičnost oštećenja sluha-novi koraci. Tematski zbornik radova. Fakultet za specijalnu edukaciju i rehabilitaciju. Beograd, 177-195.

Roksandić, I. (2016). Indikatori školskog postignuća gluvih nagluvih učenika. (doktorska disertacija). Beograd Univerzitet u Beogradu. Fakultet za specijalnu edukaciju i rehabilitaciju.

Sheridan, S.M. (1995): »Building social skills in the classroom«; in S. Goldstein (ed.): Understanding and managing children's classroom behavior (375-396). New York: John Wile\& Sons.

Suarez, M. (2000): Promoting social competence in deaf students: The effect of an intervention program. Journal of Deaf Studies and Deaf Education, 5:4, 323-336.

Tambs, K., Kvam, M. \& Loeb, M. (2007). Mental health in deaf adults: symptoms of anxiety and depression among hearing and deaf individuals. The Journal of Deaf Studies and Deaf Education, 12(1), 1-7.

Weisel, A., Most, T., Efron, C. (2005): Initiations of social interactions by young hearing impaired preschoolers. Journal of Deaf Studies and Deaf Education, 10, 2, 161-170.

Wentzel, K.R. (1991a). Relations between social competence and academic achievement in early adolescence, Child Development, 62, 1066-1078.

Wentzel, K.R. \& S.R. Asher (1995). The academic lives of neglected, rejected, popular, and controversial children, Child Development, 66(3), 754-763.

Woll, B. (2008). Mental capital and wellbeing: making the most of ourselves in the 21st century. Stateof-science review: SR-D5 Deafness and Hearing Impairment. Foresight, UK Government Office for Science. 